\title{
Strategies and Factors Development of MSME Traditional Pottery in Slahung District Ponorogo, Indonesia
}

\author{
Sri Umi Mintarti, Syahrul Munir, Dian Rachmawati, Derry Wijaya
}

\begin{abstract}
Ponorogo Regency is one of a centre for traditional pottery in East Java, Indonesia. Several problems faced by craftsmen have caused a lack of development of pottery craft businesses in the region. With a qualitative approach, this research was conducted to analyse the strategies and factors that influence the development of Micro, Small and Medium Enterprises (MSME) traditional clay pottery in the region. The methods used in collecting data include 1) Observation, 2) in-depth interviews with pottery craftsmen, pottery traders, and local government, 3) documentation, 4) conducting focus group discussions (FGD). The research show that the underdevelopment of traditional pottery craft businesses has been carried out for generations due to various factors including lack of regeneration of business managers, monotonous results of pottery crafts, weak network marketing, small business capital, and low understanding of technology information and communication. The strategies carried out by pottery craftsmen and the government to develop pottery craft businesses include optimizing community empowerment activities through training and fostering innovative technology for marketing and product development for craftsmen, forming marketing networks through the pottery craftsmen association in Slahung, Ponorogo district, village pioneering tour and education of pottery crafts, and the government synergizes with craftsmen in seeking easy access to capital.
\end{abstract}

Keywords : MSMEs, Traditional Pottery, Business Development

\section{INTRODUCTION}

The creative industry in Indonesia is an industry that is able to survive in the era of the 1997 monetary crisis, even supporting the wheels of the economy in Indonesia. This is evidenced by the achievement of the value of Indonesian exports that exceeded USD25.4 million in 2018, the value is higher than the previous year which penetrated USD25.2 million [1].

The role of the pottery industry, or better known as the pottery micro, small and medium enterprises (MSMEs), should continue to be optimized so that it truly contributes to the surrounding area and later is expected to boost the Indonesian economy. Based on data from the Central

Revised Manuscript Received on October15, 2019

* Correspondence Author

Sri Umi Mintarti, Development Economic Department, Universitas Negeri Malang, Indonesia. Email: sri.umi.fe@um.ac.id

Syahrul Munir, Development Economic Department, Universitas Negeri Malang, Indonesia.

Dian Rachmawati*, Development Economic Department, Universitas Negeri Malang, Indonesia. Email: dian.rachmawati.fe@um.ac.id

Derry Wijaya, Computer Science Department, Boston University, USA.
Statistics Agency, the contribution of the MSME sector to the Gross Domestic Product (GDP) in 2017 reached $60.34 \%$.

Slahung is one of the sub-districts in Ponorogo regency that has a number of small and medium micro business units (UMKM) pottery handicrafts which until now continues to survive. According to residents around the Pottery Industry it has become a livelihood for generations so as to say this pottery craft is local wealth for the Ponorogo area.

Based on statistics from the Ponorogo district [2], the data for all pottery craftsmen in 2017 is 160 business units. While the results of the field survey in 3 villages in Slahung sub-district, namely the villages of Plancungan, Ngloning, and Gombang, showed that there were more than 40 artisans who remained, with an average age of workers over 40 years. The craftsmen who are mostly women, until now still continue to pursue their pottery handicraft business even though arguably the results are not much.

Based on the results of the initial survey conducted, information was also obtained that when running a business the craftsmen encountered various problems including the difficulty of finding people who wanted to be the successors of the pottery business, it was difficult to market the results of the pottery craftsmanship so that marketing depended on a middleman, venture capital was still very small so the production capacity is very small, the weather sometimes disrupts the pottery business, lack of understanding of technology. This certainly needs to be explored in more detail what is actually hindering the development of their business and also need to find the right strategy to solve it. Therefore, the purpose of this study is to analyse various things that influence the development of the pottery vessel business and strategies in developing the pottery vessel business in Slahung sub-district, Ponorogo Regency, East Java.

\section{MATERIAL AND METHODS}

This study uses a qualitative approach to the type of phenomenological research. This research is taken from the phenomena that occur in Plancungan village, Ngloning village and Gombang village, Slahung sub-district, Ponorogo district, with the subject of the research of pottery craftsmen. The methods used in collecting data in this study include 1) Observing pottery craftsmen, 2) conducting deep interviews with related parties (pottery craftsmen, pottery traders, and the government), 3) documentation, and 4) focusing group discussion (FGD).

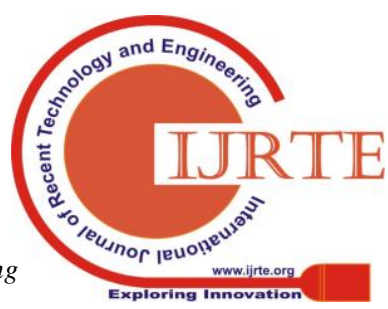


The data Analysis Technique adopted from the ideas of Stevick, Colaizzi, and Keen, namely 1) Describe the phenomena encountered in the pottery craftsmen (the initial stage); 2) Inventory important statements that are relevant to the phenomena encountered in the pottery craftsman (Horizonalization Phase); 3) Classify statements into meaningful themes and eliminate overlapping/ repetitive/ unclear statements (Cluster of Meaning Stage); 4) Reflect on the results of the description (validation and labeling stages); 5) Making a description of the meaning and essence of the overall experience (the stage of making Individual Textural Description/ IDT) $[3,4]$. To ensure the validity of the research data, the researcher triangulated the source by checking and comparing the research answers to several sources.

\section{II.FINDINGS AND DISCUSSION}

\section{A.Factors That Influence Pottery Craft Business Development}

Pottery Slahung sub-district are mostly mothers whose age is above 40 years with the majority of education being elementary schools. According to the people, as long as they were pottery craftsmen there were many obstacles that caused their businesses to be underdeveloped. The underdevelopment of traditional pottery handicraft business in Ponorogo Regency which has been carried out from generation to generation is caused by various factors including:

\section{The absence of regeneration in business management}

The absence of regeneration to continue the pottery business has become an obstacle in developing the pottery business in Slahung sub-district. Most young people are not interested in becoming pottery entrepreneurs, because in their view this pottery business is less promising, so they choose to work elsewhere. Because there is no substitute (regeneration), the business activities of the craftsmen are limited to their abilities and only what is important is the running business. Older craftsmen still try to maintain this traditional pottery business despite the less promising situation. Most of them reasoned to continue to pursue this pottery business because they want to maintain the cultural heritage of ancestors who have become local wealth in the Ponorogo area. The results of an interview with one of the craftsmen in Plancungan village, Slahung sub-district, Ponorogo Regency, namely the mother of "ZT", she has been doing this craft business for more than 70 years, they have been pursuing this business for generations as their family's inheritance. Even though he is elderly, he is still enthusiastic about stepping on the pedals to turn the pottery vessel, as shown in the following picture.

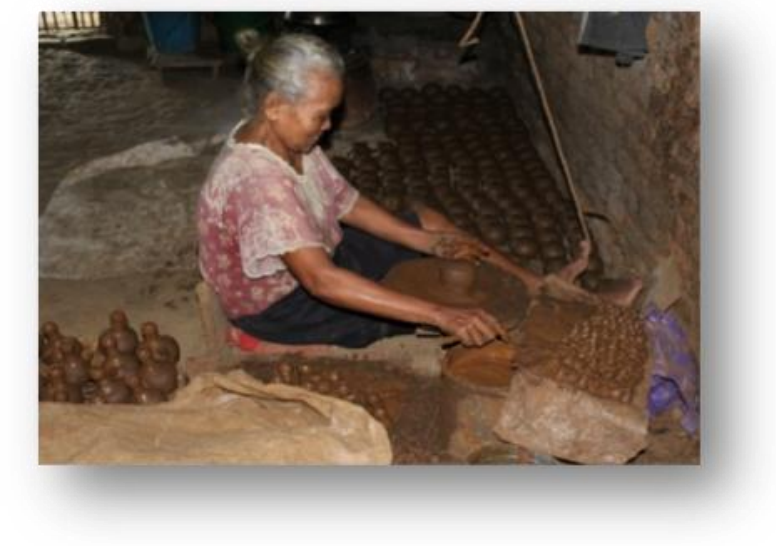

Figure 1. Craftsmen printing jugs of earthenware using traditional tools

\section{The monotonous results of pottery crafts}

The number of craftsmen whose age is quite old, also has an impact on the results of the pottery produced. With age and strength that are no longer maximum, spread to the results of crafts that are less innovative (monotonous). With the resources they have now, they have no power to create and innovate products. They do not want to make a variety of crafts with interesting creations first, then exhibited in the showroom because they are afraid their goods will not sell quickly. They prefer to produce when there are orders from consumers, so do not take too much risk. The handicrafts that have been produced according to the order are kendil, jug, placenta, pot, barrel, kreweng (clay pan), and others. The following are examples of pictures of the pottery craftsmen in Slahung sub-district.

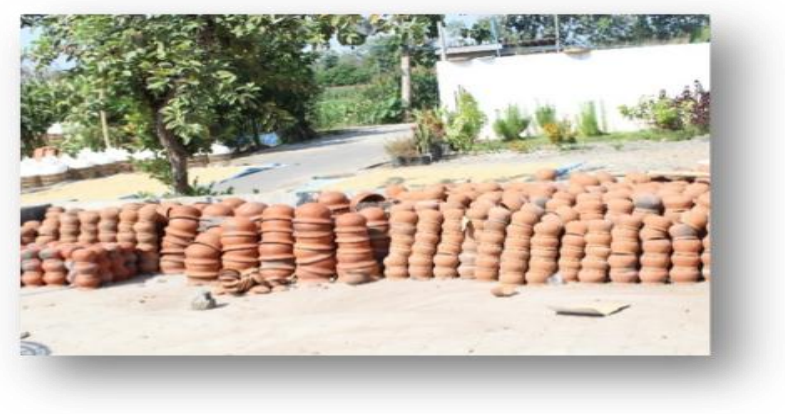

Figure 2a. "Kendil" (crockery)

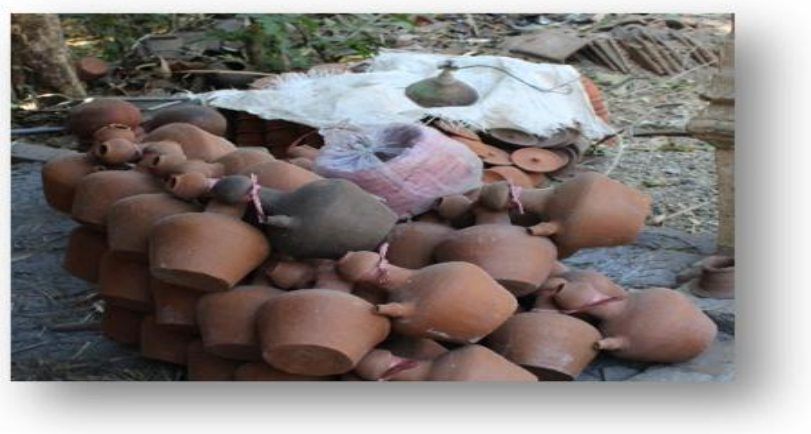

Figure 2b. "Jug" (water container) 
Figure 2a is "kendil" which is a tool for cooking rice of rural communities in East Java, Indonesia and Figure $2 b$ is "kendi" which is a place for drinking water for most villagers. Both are handicrafts from craftsmen in Slahung sub-district, Ponorogo, East Java-Indonesia. Both are handicrafts created from generation to generation, without an innovation.

\section{Small venture capital}

Based on the results of the field survey, the business capital owned by craftsmen in Plancungan sub-district on average ranges from $\mathrm{Rp} 250,000$ to $\mathrm{Rp} 600,000$. The lack of capital from these craftsmen is accompanied by less than maximum results, because with minimal capital, the production capacity is also small. In addition, the dependence on the middlemen when selling at such a low price is also the reason for the low business results. Craftsmen have no other choice to sell handicrafts than to middlemen, because they do not have a lot of marketing networks. With low capital and marketing that depend on these middlemen, they do not expect much return on investment even though they get a small profit, at least they can continue their business even if they hobbled.

\section{Weak network marketing,}

Weak marketing network of pottery craftsmen in Plancungan area, triggered by the monotonous results of their crafts. Monotonous results, with the lack of innovation and creation become one of the causes of weak marketing networks. This is because now consumers are less interested in monotonous craft materials. In addition, the weakness of this network is also caused by the lack of craftsmen unity in a community (community). Their network becomes weak, because they go their separate ways, both in determining prices, marketing locations, and even the acquisition of raw materials. The weakness of this network really has a bad impact on the craftsmen, because they inevitably depend on the middlemen, so the selling price of the craftsmen becomes very low and the profit gained becomes very small.

\section{Low understanding of information and communication technology}

Pottery craftsmen in Plancungan sub-district, the majority of which are already elderly, mostly do not keep up with the development of the current trend. Inadequate understanding of information and communication technology makes them increasingly eroded by the progress of science and technology. The progress of science and technology that should be able to help them in doing product variations and expansion of marketing networks, will actually make them increasingly left behind if they do not follow it.

\section{Dependence on nature}

Most craftsmen in Slahung sub-district initially used their own land to obtain clay as the basis for pottery. But over time they imported from outside the region, because the land was getting narrower. So it also requires a large enough cost to obtain these raw materials. This certainly affects the production activities of craftsmen, because the availability of raw materials becomes very important in the pottery business. According to craftsmen in Plancungan sub-district, besides the availability of raw materials, the production of pottery vessels is also influenced by the weather and the season where during the dry season and sunny weather, the results of the pottery drying process are very smooth and the crafts can be maximized, while during the rainy season the pottery results become ugly, because the drying process is less than optimal. This situation certainly disrupted the development of the pottery vessel business because most of the craftsmen mostly used traditional drying and combustion tools, namely using a wood burning stove (figure 3a) instead of the aluminium electric furnace image $3 \mathrm{~b}$.

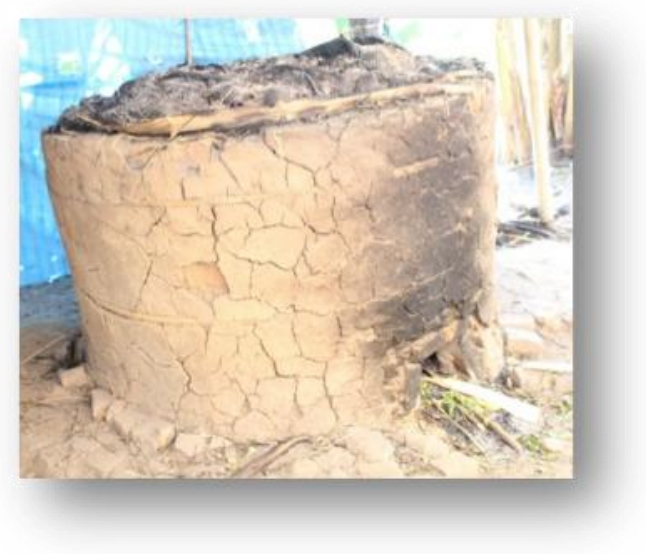

Figure 3a. Traditional pottery kiln

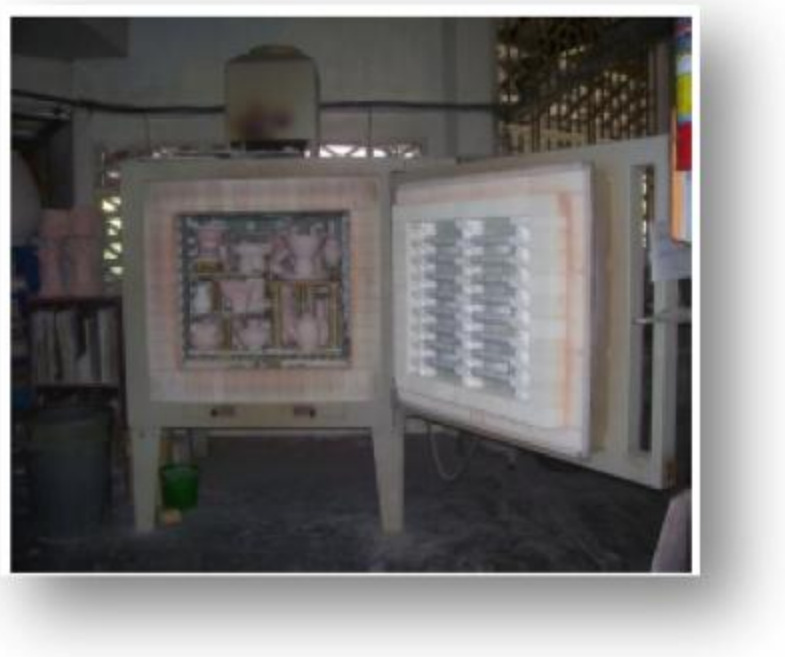

Figure 3b. Modern earthenware furnace (Aluminum material)

Figures $3 \mathrm{a}$ and $3 \mathrm{~b}$ are tools that can be used by pottery artisans. The difference between the two tools is the level of sophistication. Figure $3 \mathrm{a}$ is called "Furnace" which uses firewood for its combustion while Figure $3 b$ is "Furnace" which uses electricity to burn it. The people of Slahung, Ponorogo, East Java-Indonesia currently mostly use traditional "Stoves" (figure 3a) in burning their earthenware products, so they are very dependent on the weather conditions.

B.Development Strategy of Traditional Pottery Craft Business in Slahung sub-district, Ponorogo Regency

The people of Ponorogo in Slahung sub-district, run a pottery business with all their heart. With an average age of more than 40 years, they are still struggling to pursue a traditional pottery business. 
The small amount of business results (turnover) did not make the craftsmen break the charcoal in developing the pottery business. This spirit has inspired elements of the community starting from the local government, industry offices, and academics to work together to help the craftsmen in the Slahung sub-district develop the pottery handicraft business. Various development strategies as an effort to develop the pottery business in Slahung sub-district, for example by holding various community empowerment activities for pottery craftsmen. This community empowerment activity is a process of providing opportunities for the community to participate in the transfer of knowledge, expertise and skills. This empowerment activity, allows the creation of an increasingly independent community atmosphere and allows the development of community potential [5]. The dimension of empowerment activities as explained by [6] is basically that the potential that exists in the community is to grow and develop. Various development strategies undertaken by various elements of society in the form of community empowerment activities in Slahung sub-district are described as follows.

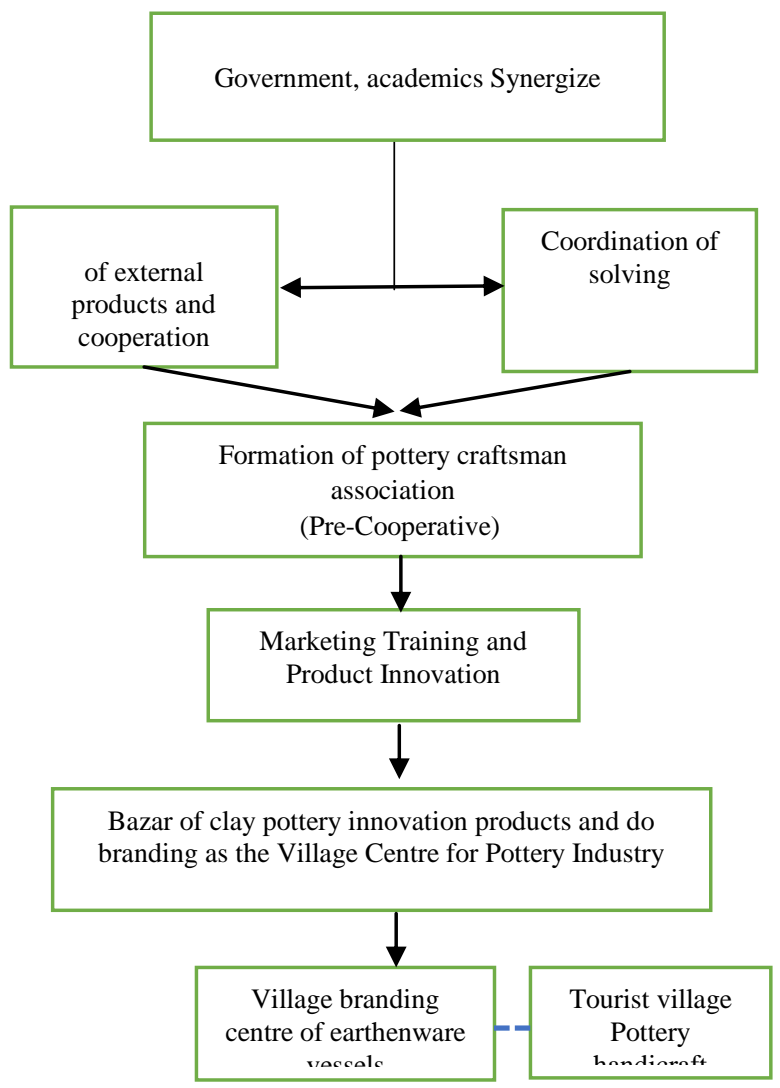

Figure 4. Strategy for the development of the traditional pottery business in Slahung sub-district, Ponorogo, Indonesia

Development strategies are explained in an effort to develop a traditional pottery business in Slahung sub-district, including:

\section{Providing Marketing training and Variation in}

\section{Production Results.}

The development of the pottery industry in Slahung sub-district is inseparable from the influence of the development/ training activities on craftsmen who have been carried out by various parties, namely the village government in the Plancungan sub-district, the Industry and Trade office, and from the academics. The synergy between the village government, industry offices, academics and craftsmen in the coaching / training activities as shown in figure 5 has a very positive impact. Guidance for the pottery craftsmen is emphasized to improve the quality of the human resources of the pottery craftsmen, so that they have the ability to improve the quality and variety of pottery products, which in turn can improve the marketing quality of pottery handicraft production. This is as expressed by [7] that "The success of a company is largely determined by the proper utilization of its human resources".

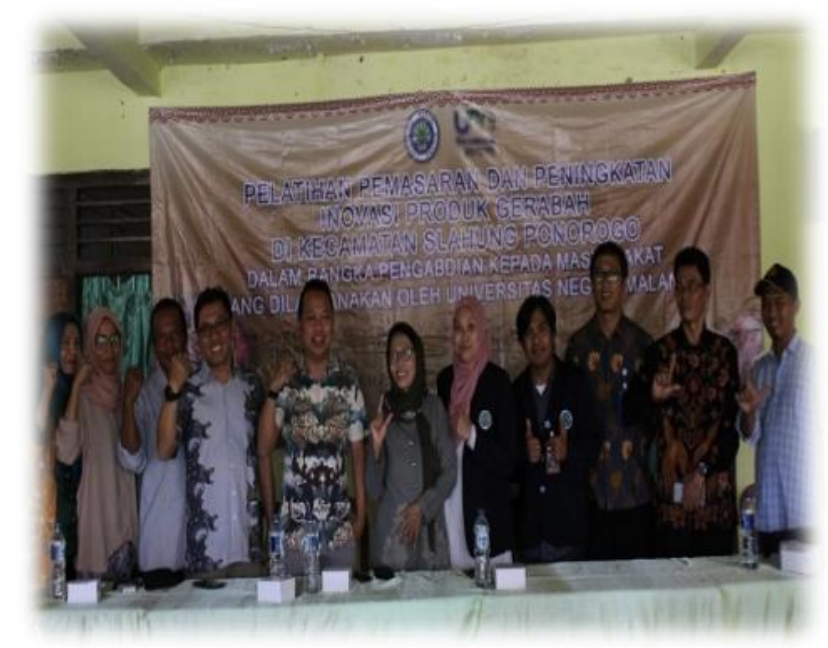

Figure 5. Synergy of elements of the community, village government, industry offices, academics, and craftsmen in training activities

Figure 5 shows the synergy of some elements of society among academics, government, and practitioners in providing training to pottery craftsmen in Slahung sub-district, East Java, Indonesia. The training provided is in the form of marketing training, and and Variation in Production Results.

\section{Formation of Community Pottery Crafts-men.}

Based on the results of observations and field observations in Slahung Ponorogo sub-district, information was obtained that the strategy to develop the pottery vessel business could be carried out by forming an association of pottery craftsmen, the purpose of which was to unite the aspirations and interests of fellow pottery artisans. The unification of the craftsmen in the community who have the same interests are expected to have the same ideals that is to develop the pottery handicraft business together. This is as Ferdinand Tonnies argues in his book [8] that the community (gemeinschaft) is a form of shared life in which its members are bound by a pure inner connection, and are eternal and natural. Through the community of craftsmen can exchange information about marketing handicrafts, product trends that are currently developing, as well as sharing orders (orders). In addition, the craftsmen can also agree on the selling price so that the results obtained no longer depend on the middleman so that the benefits can be maximized, not just returning home (turning around). 
In a community association of pottery craftsmen in Slahung sub-district, many benefits are obtained, for example in the form of developing science and technology for processing pottery products, marketing handicrafts, and accessing capital.

\section{Provision of capital assistance through village funds}

Government support in the district of Slahung, reflected in the allocation of some village funds for the development of pottery vessels, proves the existence of synergy between the government and the community of pottery craftsmen. This allocation is a breath of fresh air for craftsmen as a solution in overcoming capital problems. Craftsmen can access capital through village funds provided that through a community, as expressed by one of the village coconuts in Slahung sub-district namely the father of "NP" as the village head of Plancungan Slahung sub-district, where he said that "... to help with capital and development problems. Pottery vessels in Plancungan village, the village government allocates a portion of village funds ... ". In addition to providing capital assistance through village funds, village government governance continues to fully support efforts to develop the pottery business, namely by holding exhibitions of pottery crafts, and also working to protect copyrights from handicrafts in the village. This is consistent with research [9] which states that creativity-based MSMEs must be developed with governance that refers to institutional governance in developed countries, which includes copyright protection for creativity as a form of business incentive. All this was done with the aim of not only protecting the creativity of the craftsmen but also to make the pottery crafts more known and to increase the marketing and competitiveness of the pottery products.

\section{The establishment of a village of pottery tourism village pottery}

Various efforts and concerns from the village government, industry offices, the community, and academics towards pottery craftsmen in Slahung sub-district are a form of strategy to develop pottery handicraft businesses in the region. The form of collaboration and synergy of community elements in Slahung sub-district to develop the pottery handicraft business was realized by trying to form a pioneering pottery tourism village. In addition to exhibiting the results of the pottery vessel business as well as an educational tool for the children of the region in the form of pottery vessels which have long been a local treasure in Ponorogo district, which should be preserved by the nation's next generation. This is in accordance with the opinion of Fatmawati, et al. That the tourism village is a village that lives independently with its potential and can sell its various attractions as tourist attractions without involving investors [10].

\section{CONCLUSION}

Factors affecting pottery craftsmen in Slahung sub-district include, Pottery Craft Business Development, No regeneration in business management, Monotonous pottery handicraft products, Small business capital, Low understanding of information and communication technology, and Dependence on Nature. Various development strategies are implemented in order to develop the pottery vessel business, namely the provision of Marketing training and
Variation in Production Results, Community Formation Pottery Craftsmen, Provision of capital assistance through village funds, and the formation of village Pottery Pioneering villages.

\section{REFERENCES}

1. Kemenperin. (2018). Ekspor Tembus USD 25 Juta, IKM Gerabah dan Keramik Hias Masih Prospektif,. Retrieved from (https://kemenperin.go.id/artikel/18610/IKM-Dibidik-Tumbuh-Dua-Di git-Tahun-2018)

2. BPS. (2018). Kabupaten Ponorogo Dalam Angka: Ponorogo Regency in Figures. Ponorogo: CV. Azka Putra Pratama.

3. Creswell. (1998). Qualitative Inquiry: Choosing Among Five Tradtions. Sage Publications.

4. Moustakas, C. (1994). Phenomenological Research Methods. New Delhi. Sage Publications.

5. Kartasasmita, G. (1996). Pembangunan Untuk Rakyat-Memadukan Pertumbuhan dan Pemerataan. Jakarta: PT. Pustaka CIDESINDO.

6. Effendy, O. U. ( 2002). Hubungan Masyarakat Suatu Studi Komunikologis. Bandung: Remaja Rosdakarya.

7. Sumarsono, S. ( 2002). Ekonomi Sumber Daya Manusia Dan Ketenagakerjaan. Jember: Universitas Jember.

8. Soekanto, S. (2006). Sosiologi Suatu Pengantar. Jakarta: Raja Grapindo Persada.

9. Darwanto. (2013). Peningkatan daya saing UMKM berbasis inovasi dan kreatifitas (strategi penguatan property right terhadap inovasi dan kreatifitas). Jurnal bisnis dan ekonomi, 20, 142-149.

10. Fatmawati, EN, Satiti EN, Wahyuningsih, H. (2017). Pengembangan Potensi Desa Wisata untuk Meningkatkan Kesejahteraan Masyarakat Desa Ponggok Kabupaten Klaten. Jurnal Sekolah Tinggi Pariwisata Sahid Surakarta, 84, 98

\section{AUTHORS PROFILE}

Sri Umi Mintarti is from the Development Economic Department, Universitas Negeri Malang, Indonesia

Syahrul Munir is from the Development Economic Department, Universitas Negeri Malang, Indonesia

Dian Rachmawati is from the Development Economic Department, Universitas Negeri Malang, Indonesia

Derry Wijaya is from the Computer Science Department, Boston University, USA. 